\title{
6. Journalists' confidential sources: Reform lessons from recent Australian shield law cases
}

\section{ABSSTRACT}

That journalism, especially journalism delving into serious impropriety, relies heavily upon a journalist's ability to honour promises of confidentiality to sources, and therefore needs protection, has been well acknowledged. Former Attorney-General Philip Ruddock in proposing protection for journalists' confidential sources - commonly referred to as shield law — in the first such major federal level initiative, said ' $[\mathrm{t}]$ his privilege is an important reform to evidence law' (Explanatory Memorandum, 2007, p. 7); and in the circumstances then prevailing 'the protection of journalists is too important an issue to wait' (Philip Ruddock, Second Reading Speech, 2007). In one instance the court went so far as to say that the importance of source protection was 'entirely unexceptionable and in accordance with human experience and common sense' (Liu, 2010, para 51). Are journalists' confidential sources better protected with the advent of statutory protection in several Australian jurisdictions? The media does not think so (MEAA, 2013). Former Attorney-General Mark Dreyfus observed towards the end of his term of office: 'Recent court proceedings have highlighted the inadequacy of protections for journalists in some jurisdictions and lack of uniformity in laws across Australia' (Dreyfus, 2013). The current Commonwealth government policy in relation to national uniform shield law is unclear. The Australian shield law framework beckons reform and recent events indicate some potential reform areas.

Keywords: confidential sources, investigative journalism, media law, shield law, statutory shield

JOSEPH M FERNANDEZ

Curtin University, Perth 
USTRALIAN journalists' initial optimism at the introduction of
statutory shield protection has been afflicted by doubt following a
number of court actions to discover journalists' confidential sources. The journalism profession's peak body, the Media, Entertainment and Arts Alliance (MEAA) noted that it was 'unprecedented in Australia that so many journalists are simultaneously in this position' (Press Freedom Report, 2013, p. 16). Counsel in one of the cases noted 'a significant increase in the number of applications for disclosures of sources against the media' (Ralston, 2013). Protection for journalists' confidential sources has attracted law reform attention for about two decades (Twomey, 1992; Senate Standing Committee, 1994). The initial hurdle - whether source protection should be enshrined in statute - was overcome at Commonwealth level in 2007 with the passage of a federal shield law (Evidence Act 1995, Part 3.10, Division 1A). That underwent further reform in 2011 and the MEAA said it presented 'some cause for optimism' (Warren, 2011, p. 3). The signs for the media have been described as good although the battle is not yet won (ABC TV, Media Watch, 2013). The MEAA is pushing 'for uniform national shield laws that fully acknowledge and properly protect journalist privilege' (Warren, 2013, p. 4). Australia's multi-jurisdictional law-making framework has produced a mix of legislative measures ostensibly aimed at offering greater source protection. Where shield law has been introduced, the lawmakers claim that their provisions strike the right balance (Robert McClelland, 2010, p. 1239; Christian Porter, 2011, p. 16). The occasional judicial scepticism towards shield law, however, undermines the media's confidence in present shield law. The then Attorney-General stated at the outset: 'The new privilege will not be absolute' (Philip Ruddock, Second Reading Speech, 2007, p. 6). The media, however, is not seeking absolute protection. As one newspaper at the heart of a major shield law case wrote in an editorial:

The media is not seeking a system of open slather: The West Australian believes that the entitlement of a journalist to retain confidentiality should be open to challenge and should not apply where a journalist has no reasonable basis for believing the information provided to them was true, or if it was not a matter of public interest. (The West Australian, 2011, p. 20)

Given such unequivocal support for qualified protection how can effective shield law be achieved? This article sets out the Australian shield law back- 
drop; provides an overview of the prevailing protections; considers major recent shield law cases and some of the lessons they offer to journalists; and suggests potential reforms. This article is based on a legal analysis of recent Australian shield law cases. The way forward is not as simple as reflected in the suggestion that '[a]11 that remains is for states and territories to pass complementary legislation' (O'Shea, 2011).

\section{Overview of the law}

Two key aspects of the shield law discourse bear noting at the start. One is the legal framework and the other is the manner in which the legal framework has impacted on specific court cases. Recent cases highlight how journalists' efforts to protect their confidential sources become entangled in legal processes and intricacies, how competing legitimate interests demand consideration and how the courts respond to these competing demands. The legal framework is considered first.

\section{Statutory shield}

Following the passage of federal shield law in 2007, New South Wales became the first jurisdiction to adopt a statutory shield (Evidence Act 1995, Part 3.10, Division 1C). Since then statutory shield protection has become available in all jurisdictions except Queensland, Northern Territory and South Australia (Fernandez, 2013a, pp. 20-22). Statutory protection is available at Commonwealth level, Australian Capital Territory, New South Wales, Victoria, Western Australia and Tasmania (respective Evidence Acts, ss. 126H(1), $126 \mathrm{~K}(1), 126 \mathrm{~K}(1), 126 \mathrm{~K}(1), 20 \mathrm{I}$ and $126 \mathrm{~B}(1))$. The prosecution of Herald Sun journalists, Michael Harvey and Gerard McManus, over an article they wrote in February 2004 about the Commonwealth government's planned cutbacks to war veterans' entitlements, based on confidential documents, can be credited for long-overdue attention to the need for statutory protection for journalists' confidential sources (Bills Digest, 2009, p. 4). In that case the court refused to recognise the journalists' claim for protection, and fined the journalists $\mathrm{A} \$ 7000$, noting that the 'law does not currently recognise any "journalists' privilege"' (McManus, 2006, para 90). This led to the first major initiative in the past decade, to introduce protection for journalists' sources and this was done through the Commonwealth Evidence Amendment (Journalists'Privilege) Act 2007. That initiative also had the support of the current Attorney-General, Senator George Brandis QC (Bills Digest, 2007, p. 2). 


\section{INVESTIGATIVE JOURNALISM TRENDS}

That the statutory protections were only more recently introduced, however, does not mean that journalists refusing to disclose confidential sources before a court were totally unprotected.

\section{Common law}

The courts have long had discretion under the common law to excuse journalists from revealing their sources. In practice, however, the courts have generally not been sympathetic to journalists' claims for source protection. Several journalists have been convicted of contempt of court for refusing to disclose their confidential sources (Fernandez, 2013b, p. 139). The common law clearly does not recognise any privilege for journalists' confidential sources (McGuinness, p. 102-103; McManus, 2007, para 55; Pennells, para 76). In the McGuinness case the court cited the 'inflexible rule' denying recognition of protection for sources except in extremely limited circumstances (pp. 102-103). In the Cojuangco case, however, the court acknowledged the need for 'some restraints' on a litigant's entitlement to compel disclosure ( $p$. 354). In that case, the High Court recognised that the free flow of information is vital in investigative journalism 'which is such an important feature of our society' but noted that the courts could not go so far as to 'leave the individual without an effective remedy', for example, in respect of defamatory imputations published in the media (ibid). On such an approach, disclosure would generally not be compelled 'unless it is necessary to do justice between the parties' (Cojuangco, p. 355). In that case the court also said the 'paramount' public interest was the administration of justice (Cojuangco, p. 354). The legislature, however, could tilt the equilibrium in favour of journalists by enshrining the protection through statute. The Chief Judge in the McManus case said as much when he observed that judges are required by the law to administer the law 'and if that law is to be changed, as the journalists would have it, then their plea must be taken to the legislature' (McManus, 2007, para 62).

\section{Shield law cases}

The MEAA described the recent shield law cases as the 'relentless pursuit of journalists in expensive legal actions' (Press Freedom Report, 2013, p. 16) while a lawyer who acted in such cases noted 'an increasing number of applications for journalists to discover their sources' (Bartlett, 2013, p. 6). These cases involved Nick McKenzie, Richard Baker and Philip 
Dorling of The Age; Steve Pennells of The West Australian newspaper; Steve Lewis of News Limited; Adele Ferguson of The Age; and Paddy Manning of The Sydney Morning Herald (Press Freedom Report, 2013, p. 16). Lewis' case ended with the Federal Court deciding that he did not have to hand over a document; Manning's case was settled; and the Western Australia Supreme Court set aside Ferguson's subpoena on 7 October 2013. Each of these cases was set against unique circumstances and the pressures for disclosure in the respective cases were varied. This article focuses on three of the cases, which comprise more than one proceeding in some instances - the Bank Notes case; the Helen Liu case; and the Pennells case - as they provide some discussion on issues that arise in a shield law context. While it would be desirable to find an overarching principle to provide journalists a clear justification for an effective shield law, these cases present a fresh reminder of the challenges in trying to satisfy all sides and of the difficulty in finding a simple unifying principle that goes beyond a presumption that journalists are not required by law to reveal their confidential sources.

\section{The Bank Notes Case}

This case involved a quest for disclosure of the sources of two investigative journalists', Nick McKenzie and Richard Baker from The Age newspaper, as part of a committal hearing involving not them but former Reserve Bank of Australia bank note executives charged with bribery. A committal hearing is essentially aimed at determining whether there is enough evidence to order a person charged with an offence to stand trial or be sentenced. In this case the relevant provision was s. 97 of Victoria's Criminal Procedure Act 2009. The legal instrument used to notify the journalists of the demand was a witness summons, which required them to give evidence and produce certain documents at the committal hearing in relation to their article published in 2012 entitled 'Bagman to tell all in notes scandal' (McKenzie, 2013b, para 7). That article attributed information to a 'senior government source' and said the bagman had agreed to turn star witness and testify that several former RBA bank note executives used him to pay millions of dollars in bribes to officials in Jakarta in return for contracts (McKenzie \& Baker, 2012).

Counsel for one of the accused sought to question the journalists about a source that revealed a major development in the bribery prosecution (Press Freedom Report, 2013, p. 17). The purpose of this questioning was for a legitimate forensic purpose - that there was a connection between the attempt 


\section{INVESTIGATIVE JOURNALISM TRENDS}

to discover the journalists' sources and the issues raised in the proceedings involving the bank executive concerned. The purpose, according to the bank executive's lawyer, was to ask whether the journalists' information was accurate, who provided that information, and if it was somebody who had that information when the prosecution did not have that information 'then we can make appropriate inquiries and if necessary, we can obtain that material' (McKenzie, 2013b, para 17). These are arguably legitimate questions in the course of a fair trial.

Magistrate Phillip Goldberg ruled that there was a legitimate forensic purpose behind the issue of the summons to each of the journalists (McKenzie, 2013b, para 18). The journalists' counsel argued common law principles supporting protection of journalists' confidential sources as the then newly-passed Victorian shield law did not apply to the case (ibid). Magistrate Goldberg also noted: 'There is no law which protects, that is coded or statute law that protects or creates a rule that recognises journalist privilege' (Akerman, 2012). He was speaking in Victoria's context where the State's shield law, although it was passed, did not take effect until 1 January 2013 and even if it applied it would have been a different question whether it would have helped the journalists. The Age journalists then filed an action in the Victorian Supreme Court to quash the magistrate's decision. None of the three grounds relied on in this action, however, directly involved a claim for protection of confidential sources (McKenzie, 2013b, para 23). Among the appeal grounds were that the magistrate denied them natural justice.

The Victorian Supreme Court dismissed the journalists' application for judicial review on all three grounds. Justice Michael Sifris said the court was not concerned with the correctness of the magistrate's decision but rather whether the magistrate acted properly, within jurisdiction and complied with the law (McKenzie, 2013a, para 16; McKenzie, 2013b, paras 24-27). While it may seem curious that a court of review states plainly that it is not concerned with the correctness of a lower court's decision, the fact was that the journalists sought judicial review under court rules that were 'essentially concerned with procedure' (McKenzie, 2013a, para 16, emphasis added). In other words, the concern was not with the lower court's decision per se on the merits of any claim for source protection but with the court's decision-making process.

The journalists then appealed to the Victorian Court of Appeal against Justice Sifris' orders. This action too reveals an oddity because the appeal was 
based on 'very different' grounds from the ones before Justice Sifris and it was still unrelated to shield law (McKenzie, 2013b, para 28). These grounds included one that the judge had erred in failing to set aside the witness summonses to the journalists on the basis that they were beyond the power of that court. Although journalists generally appeared to view this case as a source protection battle, the judicial process in this case did not explicitly involve a claim for source protection. As Justice Sifris observed, it was irrelevant that the court's decision-making process, if that process were correctly approached, would result in the journalists having to reveal their sources.

This case is not about the protection of sources by journalists. It is an assessment as to whether correct procedures were followed and the law was complied with and not the substantive correctness of the Ruling. (McKenzie, 2013a, para 20)

Fortunately for the journalists, the Victorian Court of Appeal unanimously allowed the appeal, once again on a ground not argued before (McKenzie, $2013 \mathrm{~b}$, para 59). The grounds for overturning the lower court's decision did not turn on any argument for source protection, although the court acknowledged the importance of source protection (McKenzie, 2013b, para 3). To be sure, the court's remarks on this point were counter-balanced by the view that worthy as a journalist's ethical obligation on confidentiality is, it 'sometimes comes into conflict with other, equally worthy, principles - or even its own rationale' (McKenzie, 2013b, para 4).

The Court of Appeal was blunt in its summation of the bank executive's pursuit of the journalists' sources stating that he 'is in reality embarked upon a fishing expedition in the hope that something might turn up as a result of the applicants' appearance in the witness box' (McKenzie, 2013b, para 54). The court was mildly critical of magistrate Goldberg's failure to indicate how knowledge of source identity would assist in resolving the issue of legitimate forensic purpose and it observed that 'presumably he accepted' the opposite side's submission on that point (McKenzie, 2013b, para 4). The actual court proceedings in this case did not consider the merits of source protection. Also, the final outcome, favourable as it was to the journalists, was ultimately decided on a ground not argued before or decided upon by the trial judge (McKenzie, 2013b, para 54). In reaching the view that the journalists' contentions upon appeal should be allowed in the Bank Notes case, the Court of Appeal said no 


\section{INVESTIGATIVE JOURNALISM TRENDS}

court may exceed its jurisdiction or power and that the magistrate had adopted an impermissibly broad view of his power (McKenzie, 2013b, para 36). In approaching law reform, this case suggests a need to more explicitly address 'fishing expeditions'. The Western Australia shield law, which requires reasons to be given for giving or refusing to give a direction (Evidence Act, s 20J (4), provides a cue. In such situations, the courts must explain their reasons so as to guide future conduct by journalists or assist with the preparation of a challenge of a decision ordering disclosure. The WA statute requires a consideration of the 'probative value of the identifying evidence' and the 'importance of the identifying evidence' (ss. 20J (3) (a) and (b)). Such a provision could also reinforce the discouragement of 'fishing expeditions' by requiring applicants for disclosure to have a reasonable belief of their right to seek relief in court, such as is found in Federal Court Rule 7.23 (United Voice case, paras 7 and 84-86).

\section{The Helen Liu case}

This case involved a series of articles, relying on confidential sources, that claimed a link between the former defence minister Joel Fitzgibbon and entrepreneur Helen Liu. In McKenzie's and Baker's words: 'Fitzgibbon and the Labor Party received substantial political donations from Liu and he failed to declare to the Australian Parliament that she twice paid for him to travel to China' (Press Freedom Report, 2013, p. 17). Fitzgibbon denied receiving a $\$ 150,000$ payment from Liu as part of 'a campaign to cultivate him as an agent of political and business influence' and he sued The Age for defamation (Ralston, 2013). Liu filed a defamation action against three unknown defendants claiming that these sources were liable for damage to her character, credit and reputation as a result of the re-publication. She launched legal action to compel The Age and its journalists, Richard Baker, Philip Dorling and Nick McKenzie ('the journalists'), to disclose the identities of the sources that provided them with the information and documents leading to the publication of the defamatory imputations. She sought orders under Rule 5.2(2)(a) of the Uniform Civil Procedure Rules ('Rule 5') for preliminary discovery from The Age and the journalists (Liu, 2013, paras 1-3).

The New South Wales Supreme Court and the New South Wales Court of Appeal found in Liu's favour. The Age sought special leave to appeal to the High Court. The High Court refused leave (Liu, HCA). The source disclosure cases involving Liu and The Age total five (Liu, 2010; Liu, 2011; Liu, 
2012; Liu, 2013; and Liu, HCA). The New South Wales Court of Appeal was critical of the protracted hearings as they were used by the defendants to embark on an examination of the merits of Liu's claim. The court noted that this was 'not an appropriate course' in relation to an interlocutory matter where the overriding purpose was to facilitate the 'just, quick and cheap resolution of the real issues in the proceedings' and in such a circumstance it was 'quite inappropriate for contested issues of fact' to be litigated (Liu, 2013, para 103; Civil Procedure Act 2005 (NSW), s. 56).

The first hearing involved Liu's attempt to identify those who may be liable to her for claims that she corruptly paid Fitzgibbon $\$ 150,000$ ( Liu, 2010, para 1). That information, according to The Age, was quoted from documents said to be Liu's personal and business records (Liu, 2013, para 5). Liu, however, contended that at least two of the documents 'were forged or falsified' by an unknown person ( $\mathrm{Liu}, 2010$, para 2). The forgery allegation was 'critical' to Liu's application for discovery (Liu, 2010, para 12). The purpose of her Rule 5 action was to identify persons other than the journalists who may be separately liable to her although this did not absolve the journalists of any defamation claim (Liu, 2010, paras 34-35). While the court's power to order disclosure under Rule 5 is discretionary and the court may consider the public interest in source protection, the weight given to protection 'would plainly be substantially undermined in the case of a source that had used a journalist as an unwitting agent of fraud' (Liu, 2010, para 12).

The third hearing involved a closer consideration of Liu's quest for orders to the journalists to reveal their sources; how the documents were obtained; and an order to the journalists to provide all memoranda, notes, notebooks, audio recordings, video recordings, diaries, draft articles, correspondence, records of interview and other documents and papers or copies which relate to or record any interview, meetings, conversation or other actions with the source which may identify the source (Liu, 2012, para 5). The court ruled in Liu's favour. The journalists contended that the remedy Liu sought conflicted with the implied constitutional freedom of communication on matters of government and politics recognised by the High Court in the Lange $v A B C$ case (Liu, 2012, para 8). This implied freedom was developed by the High Court in a series of cases and it has been observed that, overall, it is beyond question that media organisations have been the principal immediate beneficiaries of this freedom (Chesterman, p. 311). 
The journalists argued that in light of Lange, it should now be held that the Newspaper Rule is 'absolute' as it prevents the disclosure of a journalist's confidential source that is used in discussing matters of government or politics (Liu, 2012, para 12). This was clearly an ambitious exercise and Justice Lucy McCallum rejected that argument (Liu, 2012, paras 14 and 44). The judge reminded that the Newspaper Rule is only a judicial practice of refusing to compel discovery and that 'it has always been the case that disclosure of a source will be compelled when it is necessary in the interests of justice' (Liu, 2012, para 42). The court held that giving the Newspaper Rule absolute effect in cases involving political discussion would, in essence, automatically protect sources regardless of the reasonableness or honesty of the conduct concerned. While agreeing that Rule 5 could effectively burden the implied freedom of communication, the court said the rule concerned was 'reasonably appropriate and adapted' to serve a legitimate end - to allow for the identification of a person for the purpose of seeking a remedy allowed under a constitutionally prescribed system of representative and responsible government (Liu, 2012, para 61). The court said the protection of sources 'is not a right or an end in itself' (Liu, 2012, para 203).

The court also found that Liu was not motivated by an improper purpose and intention ( Liu, 2012, paras 106 and 108). Furthermore, the defendants did not dispute that Liu had a valid claim in defamation against the sources ( Liu, 2012, para 118). Notwithstanding the decision going against the journalists, the court said the case sat 'uncomfortably on the fault-line of strong, competing public interests' and this was complicated by the positions of the plaintiff and the defendants resting on conflicting factual contentions (Liu, 2012, para 168). On the one hand the journalists' were claiming that following lengthy and careful negotiation they obtained documents showing the making of corrupt payments by the plaintiff to a Federal MP, and that the sources genuinely feared reprisal if their identities were revealed (Liu, 2012, para 169). On the other hand, the plaintiff argued that someone with a vendetta against her provided deliberately forged documents that they falsely attributed to her and that to deny her relief would perpetuate the fraud (Liu, 2012, para 170). The journalists then appealed to the New South Wales Supreme Court but lost the appeal in a unanimous decision ( Liu, 2013). The fifth part of the hearing involved a request for special leave to the High Court, to seek constitutional recognition for the Newspaper Rule. The High Court rejected the application for leave. 
Some factors appeared to undermine the claim for source confidentiality in this case, a significant one being the question of whether documents relied on in the articles were forged. The journalists' position was that 'the sources were credible and could be trusted to provide accurate and truthful information concerning the plaintiff' ( $L i u, 2010$, para 21). While no determination was made on the point, as the court was not required to at this stage, the court said that the handwritten documents relied on by the defendants 'may well have been falsely attributed' to Liu (Liu, 2012, para 188).

A further factor that undermined the journalists' claim to confidentiality appears to be that one of the defendants (Baker) disobeyed a specific request from the sources not to publish certain handwritten papers that had been 'included inadvertently' among the documents provided (Liu, 2012, paras 200-201). Contrary to that request, however, The Age published details of the handwritten papers on its front page. In the end this case did not determine the merits of the journalists' claim for source protection. It was an interlocutory matter and the journalists' failed in their attempt to have the merits of source protection considered. As such, this case offers limited lessons in the context of the present discussion. One clear lesson from this case, however, is journalists must be extremely cautious about the materials that they rely upon for stories, especially those with the potential to cause serious harm.

\section{The Pennells case}

While it is referred to here as the Pennells case, journalist Steve Pennells and his publisher WAN Ltd were only Third Parties in a dispute that was between mining magnate Gina Rinehart and members of her family. Other related hearings are not important for present purposes. Of present significance is the fact that Pennells and his newspaper publisher had been subpoenaed to produce documents to the arbitrator who was presiding over a commercial arbitration (Pennells, paras 1-4). On one side was Hancock Prospecting Pty Ltd (Rinehart) and on the other side were ten Respondents, among them the Rinehart children, John, Bianca and Hope. Rinehart and the Respondents were parties to arbitration under Western Australia's Commercial Arbitration Act 1985 (' $C A A c t$ '). It was in the course of that arbitration that the Court issued subpoenas to Pennells (HPPL later abandoned its direct pursuit of Pennells) and his publisher WA Newspapers Ltd (WAN), on HPPL's application, under s 17(1) of the CA Act. That section allows any party to an arbitration agreement to issue a subpoena to produce documents 
specified in the subpoena (Pennells, para 15). Section 17(2) of that Act, however, protects against disclosure, where that disclosure cannot be compelled on the trial of an action (Pennells, paras 16 and 114). Taken with Western Australia's shield law, this factor was significant in the final outcome in Rinehart's source pursuit.

The subpoena to WAN sought the production of copies of recordings or notes of conversations between Pennells or any other WA journalist relating to subjects of a number of articles in The West 'in which he referred to a dispute between Gina Rinehart and some of her children' and 'more generally to the affairs of the members of the Rinehart family, and to the business of HPPL and related companies' (Pennells, paras 12 and 14). WAN sought to set the subpoena aside citing three grounds, including that the subpoena served 'no legitimate forensic purpose' because the documents were not relevant to the arbitration (Pennells, para 5); and that the subpoena was 'oppressive or constitutes an abuse of process' (Pennells, paras 6 and 44). Initially, WAN's factors to set aside did not include Shield Laws because of a 'timing' issue - the law only came into operation later, on 21 November 2012. Once it came into force WAN relied on the WA shield law as providing an 'additional factor' to argue that the subpoena was 'oppressive and an abuse of process' (Pennells, para 45).

WAN's application succeeded in part 'on the ground that the subpoena is oppressive and constitutes an abuse of process, having regard to the shield laws' (Pennells, para 8). This was the first time such an outcome was achieved in reliance on shield law and it was the first test for the newly-enacted WA shield law. On 6 August 2013 the court ruled that the subpoena should be set aside, save to the extent that it sought the production of documents which already identified the sources (Pennells, paras 126 and 232). In this case, while some of the documents sought were received on condition of source anonymity, some were not. WAN relied on other grounds to defeat the subpoena but those grounds were rejected (Pennells, para 46). The court also rejected WAN's arguments on the Newspaper Rule for the same reasons seen above. In the result, it was enough for the court to rely on the WA shield law to excuse WAN from disclosure, without having to consider other grounds that WAN relied on. As Justice Janine Pritchard said plainly:

[I]n my view the operation of the Shield Laws is a factor sufficient of itself to warrant the conclusion that the subpoena is oppressive and an abuse of process. (Pennells, para 85, emphasis added) 
The court overcame the 'timing' issue by finding that the shield law protection applied in relation to undertakings given before the commencement of the shield law provisions, if the proceedings concerned had not yet begun and in this case the 'substantive hearing of the arbitration' had not yet begun (Pennells, paras 128 and 132). As to why would it be oppressive and an abuse of process to require disclosure, the court accepted that it was 'very unlikely' or 'highly unlikely' that disclosure would be required during arbitration taking into account the WA shield law found in ss. 20I and 20J of the Evidence Act of Western Australia (Pennells, paras 142 and 167). To require disclosure 'would wholly undermine the protection' under the shield law, set out in s. 20I (Pennells, para 168). That section establishes a presumption that a journalist or the employer cannot be compelled to give identifying evidence. While it was only a presumption rather than an entitlement it was sufficient in this case to provide the shield protection sought.

\section{Lessons from the cases}

While an overarching principle that will provide journalists the key to the protection that they seek for confidential sources would go a long way to the formulation of a clear and forceful rule providing 'effective' protection, such a principle will prove elusive as long as the goal is not absolute protection, such as is available in some United States jurisdictions. One such US provision is s. 12-21-142 of the Alabama Code (Middleton \& Lee, 2013, pp. 547-548). The recognition of the desirability of journalist confidential source protection beyond the journalism community, embracing legislators and the courts, provides a good foundation to build upon. Against the above backdrop, and further to the 'lessons' already identified above, two further observations may be made.

\section{The Newspaper Rule}

This rule has been described as being 'shrouded in uncertainty' (Cojuangco, pp. 351-352) and the above cases reinforce the courts' position that this rule is not a rule at all but simply a practice to guide the exercise of the court's discretion whether to require disclosure (Pennells, para 75; Liu, 2012, paras 14 and 44; Liu, 2013, para 91). The courts have acknowledged that important public information is more readily supplied to journalists when journalists are able to honour their promises of confidentiality. A long line of authority, however, shows that the rule does not confer on journalists any immunity 
from disclosure because of the overriding public interest in the administration of justice which demands that courts must not forfeit their duty and right to access relevant and admissible evidence. Furthermore, the High Court sees no prospect of success in trying to give the rule constitutional force in respect of communications that fall within the implied freedom of political communication (Liu, HCA). While this demonstrates that the Newspaper Rule itself stands no chance of fully serving the object of a journalist source privilege it may be invoked in limited circumstances to protect journalists' sources. It also reinforces the view, more recently expressed by Professor Gelber, that the implied freedom of political communication, which was initially hailed as a free speech saviour, 'is possibly weaker in its operation now than at any time since its introduction in 1992' (Gelber, 2013, p. 7). Some two decades on there is little progress in identifying what counts as political communication (Campbell \& Crilly, 2011, p. 60).

Scope of shield law

The first point about the scope of protection would be to ensure that all jurisdictions are served by shield law. As noted earlier, three jurisdictions do not have statutory protection for journalists' confidential sources. Where such law is available, the provisions in place vary, for example, in relation to who may claim protection and in the course of what activity. In the New South Wales Act the meaning of 'journalist' appears narrower than that of the Commonwealth Act (ss. 126J; and 126G(1), respectively; Butler \& Rodrick, 2012, p. 445). The argument for a wide or narrow definition is not clear-cut. Among the causes of this uncertainty are the worldwide digital revolution, the state of flux in the journalism profession; and the parameters of professionalism for a claim to privilege. While the media industry, in particular, favours a broad definition that encompasses mainstream and non-mainstream media and traditional and non-traditional forms of journalistic activity such a position inevitably broadens the field of potential protection claimants and potential circumstances in which the protection is sought.

It should be hardly surprising that the wider the range of evidence that is sought to be withheld from the court 'the more reluctant will judges be to exercise discretion in favour of doing so’ (Brandis, 2011). A further consideration is the range of forums, judicial and otherwise, to which claims for protection would apply. In Western Australia, for example, the privilege applies to any proceeding even if the law of that proceeding says the shield 
does not apply (s. $20 \mathrm{H}(3)$ ). The Act expressly provides, however, that the statutory protection does not apply directly to a proceeding before either House of Parliament or a Committee of either House in which evidence may be given. For the protection to be effective in the media's eyes, it should cover all forums in which journalists might face a demand for disclosure, extending beyond the courts to cover, for example, parliamentary proceedings, royal commissions, corruption and crime commissions and other commissions of inquiry where evidence may be taken.

A similar observation can be made in respect of the applicability of shield law protection to particular legal mechanisms that may be deployed to discover confidential sources. One such mechanism arose for consideration in the Pennells case where the disclosure was sought under a subpoena. The court in that case found it 'curious' that the Western Australia parliament did not include in the Evidence Act a provision like s. 131A, Evidence Act 1995 (NSW), which expressly allows for an objection to the production of documents under subpoena. As the court said, such an omission could mean that 'the very protections the Shield Laws are designed to provide could be significantly undermined, if not rendered nugatory' (Pennells, para 104). The NSW provision provides a list of situations in which objections may be made to disclosure covering not only a subpoena, but also to a number of other situations and this should form a basis for preventing such a lapse in a uniform shield law. Law reform in this area should provide for the variety of such situations and put the reach of shield law beyond doubt.

Another apparent bugbear in framing the scope of the shield law has been the long list of factors that a court may take into account in exercising its discretion to order disclosure. The length of the list may have unjustifiably undermined the media's confidence in the utility of the WA shield law because it gave the appearance of difficult hurdles in the media's path. As it turned out in the Pennells case, however, they were surmountable hurdles. The list of factors set out in s. 20J include any likely adverse effect of the disclosure on the informant's or another's identity; and the public interest in the news media's communications of facts and opinions and access to sources of facts. This is accompanied by a non-exhaustive list of factors in s. 20J(3), including the probative value of the evidence; the nature and gravity of the relevant offence; cause of action or defence; and the likely effect of the identifying evidence, including the harm that could be caused to the informant or others. The 


\section{INVESTIGATIVE JOURNALISM TRENDS}

listing of these factors, rather than actively constraining the shield law's reach, provides clarity as to the factors that could play a role in the court's decision and should serve as a guide to the media when contemplating confidentiality undertakings. The Western Australia shield law-largely the handiwork of former Western Australia Attorney-General Christian Porter-has been described as 'one of the most intelligent attempts so far-not only in Australia, but also worldwide' (Brown, 2011).

\section{Caution on uniformity}

The ideal of uniform shield law has been repeatedly stated (Philip Ruddock, Second Reading Speech, 2007; Warren, 2013, p. 4). This, however, does not mean there is unanimity as to the need to statutorily enshrine source protection or as to the content of the shield. While there are strong justifications for seeking uniform rules governing journalist-source confidentiality- the attainment of clarity and certainty being among them - such uniformity must not be pursued at the expense of effective source protection. Arriving at the present point where the majority of jurisdictions have enacted protection of one form or another has taken considerable time and effort, and the 'conversion' of shield law doubters. Important shield law reform work lies ahead to ensure that all concerned can proceed with certainty that where iniquity, injustice and impropriety fester journalists can continue to perform their vital role in exposing it, safe in the knowledge that they can invoke a core ethical principle of journalism - to respect confidences.

\section{Conclusion}

A media industry coalition, Australia's Right to Know, which commissioned a free speech audit noted:

There is a good case for an effective shield law regime based on a presumption that sources should not be revealed and a journalist could only be ordered to do so by a judge on strictly limited grounds of compelling public interest. (Moss, 2007, p. 73)

It reinforces the established common understanding on all sides of the debate that the shield envisaged is a qualified one. In the absence of absolute protection, the protection offered to journalists' confidential sources could only be one that balances the competing interests (Cojuangco, pp. 354-5; McKenzie, 2013b, paras 3-4; Pennells, para 151; Evidence Act 1906 (WA), s 20J). 
A failure to acknowledge this rationale will give rise to unilateral claims for protection ( $\mathrm{Liu}, 2012$, para 204). It would be too much to expect courts and other bodies exercising judicial functions to forfeit their power to compel disclosure at the expense of their ability to do justice between the parties. Once this limit on source protection is conceded, what remains to be done is to ensure that the circumstances in which disclosure is compelled adequately heed the interests of the free flow of information and the important public interest served by the investigatory work that journalists do.

The arguments supporting the broad case for protection of journalists' confidential sources can be taken as settled - to the point of being deemed as 'common sense' (Liu, 2010, para 51). The media is also entitled to expect that once the threshold is crossed as to whether journalists' sources deserve protection, and once that crossed threshold is reflected in statute as a journalists' privilege, there must be no questioning of the existence of such a privilege, as has happened on some occasions (Fernandez, 2013a, p. 20). Journalists for their part must be prepared to forego protection where the reasonableness of their claim for protection is open to serious question. Reliance on tainted information - for example, reliance on information provided by sources with malafides or reliance on forged documents - or a failure to properly consider the withdrawal of consent to use certain information, could undermine the claim for protection. The journalist's dilemma faced in this respect can, to some extent, be avoided by making a promise of confidentiality conditional upon the journalist's ability to revoke the promise in the case of deliberately false information ( $L i u, 2012$, para 60).

Until effective protection of journalists' confidential sources is attained, journalists will be under pressure to penetrate the fortresses that obstruct the flow of 'public concern' information and must 'learn smarter ways of working to ensure we can protect our sources and their information' (Warren, 2013, p. 4). Ewart et al note that 'the post-9/11 counter-terror regime has already impacted upon journalists' access to sources and court information, their information gathering and data storage protocols, and their relationship with sources, particularly those in counter-terror agencies' (2013, p. 131). That journalists must on occasion resort to questionable methods of accessing information should come as no surprise. It is a reality fomented by considerable obstacles in the way of information flow and the overriding public interests journalists consider themselves to be serving. The Australian Law 
Reform Commission, for instance, has identified 506 secrecy provisions in 176 pieces of primary and subordinate legislation and about 70 percent of the statutory secrecy provisions identified creates criminal offences (Australian Law Reform Commission, 2009, paras 3.20-3.21).

Shield law is part of the jigsaw in a complex information control framework that incorporates legislation such as those governing secrecy, privacy, freedom of information and national security. The cases discussed above contribute modestly to an understanding of where to place the fulcrum on the scales weighing the competing interests. In the meanwhile, journalists must continue to evaluate the risks of relying on confidential sources. They face the choice of yielding to the chilling effect of weak source protection or placing themselves and their sources in harm's way by relying on confidential sources or by engaging in questionable information gathering methods with its attendant risks of moral, ethical and legal compromises. Veteran investigative journalist Chris Masters notes how, ' $[\mathrm{w}]$ hen processing unattributable intelligence we took care to code and organise key information without identifying references such as phone numbers' (Masters, 2013, p. 17). Pearson offers further caution: 'Be extra careful if you are dealing in this area. Surveillance and monitoring is so prevalent and sophisticated today that it is very hard to keep any source confidential or secret' (Pearson, 2012, p. 124). An excessive resort to questionable information gathering techniques, however, could undermine the journalism profession's legitimacy in holding others to account. Excluding such measures from a journalist's professional arsenal, however, also risks undermining the core function of journalism in a democratic society. As the European Court of Human Rights noted in the Goodwin case, 'freedom of expression constitutes one of the essential foundations of a democratic society and that the safeguards to be afforded to the press are of particular importance' (para 39). At the heart of the matter lies another significant conundrum. A key argument advanced for a stronger shield is the facilitation it will bring to information flow. That very shield, however, rests on a claim to restrict the flow of information that the courts may need to rely on for the proper administration of justice. 


\section{References}

ABC Television, Media Watch (2013, September 16). Shield laws up, but not quite there. Retrieved from www.abc.net.au/mediawatch/transcripts/s3850030.htm

Akerman, P. (2012, December 20). Two Fairfax journalists lose court bid to protect confidential sources. The Australian. Retrieved from www.theaustralian.com.au/ media/the-age-journalists-lose-court-bid-to-protect-confidential-sources/storye6frg996-1226541107638

Australian Law Reform Commission. (2009). Secrecy laws and open government in Australia, Report 112. Australia: Author.

Bartlett, P. (2013). The year in Australian media law. Media, Entertainment and Arts Alliance Press Freedom Report, Power, protection \& principles: The state of press freedom in Australia 2013, 4-7.

Bills Digest No 172. (2007, June 8). Evidence Amendment (Journalists' Privilege) Bill 2007. Parliament of Australia.

Bills Digest No 130. (2009, May 11). Evidence Amendment (Journalists'Privilege) Bill 2009. Parliament of Australia.

Brandis, G. (2011, March 23). Greens amendments a serious setback. The Australian. Retrieved from www.theaustralian.com.au/national-affairs/opinion/greenamendments-a-serious-setback/story-e6frgd0x-1226026347126

Brown, A. J. (2011, November 18). Whistleblower reform gets jump on Canberra. The Australian. Retrieved from www.theaustralian.com.au/business/legal-affairs/ whistleblower-reform-jump-on-canberra/story-e6frg97x-1226198319880\#

Butler, D. \& Rodrick, S. (2012). Australian media law (4 ${ }^{\text {th }}$ ed). Pyrmont, NSW: Thomson Reuters (Professional) Australia Limited.

Campbell, T. \& Crilly, S. (2011). The implied freedom of political communication, twenty years on. University of Queensland Law Journal, 30(1), 59-78.

Chesterman, M. (2000), Freedom of speech in Australian law: A delicate plant. Hants, England: Dartmouth Publishing Company.

Christian Porter MLA. (2011). Explanatory memorandum, Evidence and Public Interest Disclosure Amendment Legislation Bill 2011 (WA) 16, (Western Australia Attorney-General).

Dreyfus, M. (2013, June 19). Law and justice ministers to revisit journalist shield laws (Media Release). Retrieved from www.sclqld.org.au/lu/items/mediareleases $/ 445$

Ewart, J., Pearson, M., \& Lessing, J. (2013). Anti-terror laws and the news media in Australia since 2001: How free expression and national security compete in a liberal democracy. Journal of Media Law, 5(1), 104-132, 131. http://dx.doi. org/10.5235/17577632.5.1.104

Fernandez, J.M. (2013a), States create a maze of shield laws. In Media, Entertainment and Arts Alliance Press Freedom Report, Power, protection \& principles: The state of press freedom in Australia 2013, 20-22.

Fernandez (2013b). Media law in Australia: Principles, pitfalls and potentials. Perth: Black Swan Press.

Gelber, K., (2013). New developments in political speech case law. Electoral Regulation Research Network/Democratic Audit of Australia Joint Working Paper Series, 1-7. 
Masters, C. (December 2013-February 2014). Are you carrying protection? The Walkley Magazine, Issue 78, 17.

McKenzie N. \& and Baker R. (2012, December 8), Bagman to tell all in notes scandal. The Sydney Morning Herald. Retrieved from www.smh.com.au/national/bagmanto-tell-all-in-notes-scandal-20121207-2b18x.html

Middleton, K. R. \& Lee, W.E. (2013). The law of public communication $\left(8^{\text {th }} \mathrm{ed}\right)$. Boston: Pearson.

Moss, I. Chair. (2007). Report of the independent audit into the state of free speech in Australia, October 31. Sydney: Australia's Right to Know Coalition.

O'Shea, L. (2011). Shield laws. Alternative Law Journal, 36(2), 129. Retrieved from www.altlj.org/news-and-views/downunderallover/duao-vol-36-2/124-shield-laws

Pearson, M. (2012). Blogging \& tweeting without getting sued: A global guide to the law for anyone writing online. Crow's Nest, NSW: Allen \& Unwin.

Philip Ruddock MP. (2007). Explanatory memorandum, Evidence Amendment (Journalists; Privilege) Bill 2007 (Commonwealth). Retrieved from www.austlii.edu. au/au/legis/cth/bill_em/eapb2007411/memo_0.html

Philip Ruddock MP. (2007, May 24). Second reading speech, Evidence Amendment (Journalists, Privilege) Bill 2007. Commonwealth, Parliamentary Debates, House of Representatives, Parliament of Australia. (Commonwealth Attorney-General).

Press Freedom Report. (2013). Shield laws and confidential sources. Media, Entertainment and Arts Alliance Press Freedom Report, Power, protection \& principles: The state of press freedom in Australia 2013, 16-18.

Ralston, N. (2013, September 6). Helen Liu defamation case: Age journalists ordered to reveal sources. The Sydney Morning Herald. Retrieved from www.smh.com. $\mathrm{au} /$ national/helen-liu-defamation-case-age-journalists-ordered-to-reveal-sources20130906-2ta8g.html

Robert McClelland MP. (2010, October 25). Evidence Amendment (Journalists' Privilege) Bill 2010, Commonwealth, Parliamentary Debates, House of Representatives. Parliament of Australia. (Commonwealth Attorney-General).

Senate Standing Committee on Legal and Constitutional Affairs. (October 1994). First report of the nquiry into the rights and obligations of the media: Off the record (Shield laws for journalists' confidential sources). Parliament of Australia.

Twomey, A. (1992, August 12). Law and policy of protecting journalists' sources, Background Paper No 15. Law and Government Group.

WA still waits for laws to protect media. (2011, March 24), The West Australian, 20. [Editorial].

Warren, C. (2011). Media, Entertainment and Arts Alliance Press Freedom Report, Public good, private matters: The state of press freedom in Australia 2011, 3.

Warren, C. (December 2013-February 2014). Every move you make..., The Walkley Magazine, Issue 78, 4. 


\section{Cases}

Goodwin v UK (1996) 22 EHRR 123 (Grand Chamber, ECHR).

Hancock Prospecting Pty Ltd v Hancock [2013] WASC 290 [Pennells].

John Fairfax \& Sons v Cojuangco (1988) 165 CLR 346 [Cojuangco].

Lange v Australian Broadcasting Corporation (1997) 189 CLR 520.

Liu v The Age Co Ltd [2010] NSWSC 1176 [Liu, 2010].

Liu v The Age Co Ltd [2011] NSWSC 53 [Liu, 2011].

Liu v The Age Co Ltd [2012] NSWSC 12 [Liu, 2012].

McGuinness v Attorney-General (Vic) (1940) 63 CLR [McGuinness].

McKenzie v Magistrates' Court of Victoria [2013] VSC 2 [McKenzie, 2013a].

McKenzie v Magistrates' Court of Victoria [2013] VSCA 81 [McKenzie, 2013b].

Michael Harvey and Gerard McManus v County Court of Victoria [2006] VSC 293

[McManus, 2006].

$R v$ McManus and Harvey [2007] VCC 619 [McManus, 2007].

The Age Co Ltd v Liu [2013] NSWCA 26 [Liu, 2013].

The Age Co Ltd v Liu [2013] HCATrans 205, 6 September 2013 [Liu, HCA].

United Voice v Accolade Wines Australian Ltd [2013] FAC 285.

\section{Legislation:}

Civil Procedure Act 2005 (NSW).

Commercial Arbitration Act 1985 (WA).

Evidence Amendment (Journalists' Privilege) Act 2007 (Cth).

Evidence Act 1995 (Cth).

Evidence Act 2011 (ACT).

Evidence Act 1995 (NSW).

Evidence Act 2001 (Tas).

Evidence Act 2008 (Vic).

Evidence Act 1906 (WA).

Federal Court Rules 2011.

Associate Professor Joseph M. Fernandez heads the Journalism Department at Curtin University and has taught media law since 1999. This article is developed from a paper presented at the Journalism Education Association of Australia (JEAA) conference, Redrawing the Boundaries: Journalism Research, Education and Professional Culture in Times of Change, Mooloolaba, Queensland, 2-4 December 2013. Dr Fernandez is the author of Media Law in Australia: Principles, Pitfalls and Potentials (2013), Perth: Black Swan Press. The author thanks the referees for their helpful comments. j.fernandez@curtin.edu.au 